\title{
ZODPOVEDNOSŤ NAPLNENÁ OBAVAMI I NÁDEJOU Z BUDÚCNOSTI - JONASOV A SKOLIMOWSKÉHO PRÍNOS K ENVIRONMENTÁLNEMU MYSLENIU
}

DUŠAN ŠPIRKO, Katedra filozofie, Filozofická fakulta, Univerzita Konštantína Filozofa v Nitre, Nitra, SR

ŠPIRKO, D.: Responsibility Full of Fear and Hope from Future - Jonas’s and Skolimowski's Contribution to Environmental Thinking

FILOZOFIA, 74, 2019, No 5, pp. 405-413

The main subject of this essay is philosophic-ethical principle of responsibility in environ-mental context. Particularly it is concerned to the contribution of $\mathrm{H}$. Jonas and H. Skolimowski in this area. Skolimowski derives the environmental responsibility from the principle of sanctity of life. From this principle result of the ethical imperative of reverence from life (Schweitzer) and sanctity of earth as well (Leopold). The reverence from life is a point of departure to another value of environmental ethics - responsibility for life and earth. Skolimowski recommend the respectful or thoughtful development as the new form of development giving the sustainability to our planet and dignity to all people. In the Jonas's concept of ethics for technological civilization therefore it is the fear that present the important motivational and correcting factor. Jonas proposes the original concept of heuristics of fear. From the aspect of responsible policy should have a bad prognosis (which misgive) priority to good prognosis. The fear of negative distant effects would us to motivate to avoid certain action even though it could bring us a short-time effect. Jonas proposes a new categorical imperative that should help us to manage role of responsible shepherd of nature: "Act so that the effects of your action are compatible with the permanence of genuine human life!" We must ensure that the effects of our actions do not destroy future genuine human life.

Keywords: Environmental responsibility - Responsibility for future - Fear Anxiety - Hope - Jonas - Skolimowski

V našej eseji sa budeme venovat' jednému z hlavných filozoficko-etických východísk súčasného environmentalizmu ${ }^{1}$ - princípu environmentálnej zodpovednosti (pozri St’ahel 2015). K jeho rozpracovaniu významnou mierou prispeli H. Skolimowski, a najmä H. Jonas.

\footnotetext{
${ }^{1}$ R. St’ahel $(2018$, 3) charakterizuje environmentalizmus ako „smer súčasnej politickej filozofie, ktorý vychádza z reflexie príčin a možných následkov globálnej environmentálnej krízy ako jedného z najvážnejších ohrození predpokladov existencie súčasného ekonomicko-politického systému i globálnej civilizácie vôbec".
} 
V Skolimowského systéme environmentálnej (ekologickej) etiky² je jej základná hodnota ${ }^{3}$ zakotvená v princípe posvätnosti života: „Prijatie posvätnosti života nás vedie $\mathrm{k}$ ochrane iných foriem života, vedie nás $\mathrm{k}$ ochrane prírodného prostredia rovnako ako l'udského životného prostredia, v ktorom je život ohrozený... akonáhle sa premisa o posvätnosti života spochybňuje alebo odmieta, celá stavba ochranárskych stratégií a všetky akcie na ochranu životného prostredia visia vo vzduchu. Potom chýba reálny dôvod na to, aby sme sa angažovali v ochranárskej stratégii a ekologickej etike" (Skolimowski 1996, 141).

Zo základnej hodnoty posvätnosti života vyplýva etický imperatív úcty kživotu (Skolimowski 2001, 339), ktorý presadzuje aj A. Schweitzer (1996), ako aj princíp posvätnosti zeme A. Leopolda (1996).

Úcta k životu je východiskom $\mathrm{k}$ d’alšej hodnote environmentálnej etiky zodpovednosti za život a Zem: „Zodpovednost' je etický princíp v tom zmysle, že akonáhle chápeme jednotu života a skutočnosti, že sme sami súčastou tejto jednoty, že sme so životom prepojení, potom musíme prevziat' zodpovednost' za život, za všetok život...“ (Skolimowski 1996, 144).

Zodpovednost' je aj spojovacím článkom medzi etikou a racionalitou. Racionalita bez zodpovednosti je obludná (napríklad skutky nacistov). Etika bez zodpovednosti je prázdna. Čím väčši rozsah zodpovednosti na seba berieme, tým viac rastieme vo svojej ludskosti. Ak nepreberáme žiadnu zodpovednost', sotva sme l'udia (tamže). ${ }^{4}$

Podla H. Jonasa pri koncipovaní etiky pre technologickú civilizáciu - teda etiky zodpovednosti za budúce, vzdialené následky konania ${ }^{5}$ - nie je princíp posvätnosti života dostatočne účinný bez prijatia dôležitého motivujúceho a korigujúceho činitel’a. Tým je pre zodpovedné l'udské správanie zamerané do budúcnosti strach. Aby sme sa vyhli možným negatívnym dôsledkom nášho konania, musíme si uvedomit' možné hrozby - musíme sa ich zhrozit! V súčasnej realite „nám iba predvídaná deformácia človeka dovol'uje vytvorit’ pojem tohto človeka, ktorého treba pred touto deformáciou chránit'; potrebujeme teda, aby

\footnotetext{
${ }^{2}$ Opierame sa najmä o českú verziu Skolimovského textu Ekologická etika a posvátnost života (1996 preklad I. Míchal) pre adekvátnejšiu terminológiu, než akú má neskorší slovenský preklad (P. Štekauer, L. Štekauerová) (Skolimowski 1999, 188 - 211). Okrem toho je v češtine dostupná jeho d’alšia práca Účastná mysl (2001), kde sa tiež venuje tejto problematike. Stotožňujeme sa s názorom, ktorý tu vyjadril, že etika postavená na úcte k životu neimplikuje nevyhnutne druhovú rovnost' a že ani nemôže byt' neantropocentrická (339 - 342) (pozri Špirko 1996 a 2011).

${ }^{3}$ Podl'a Skolimowského $(1996,140)$ v každom etickom systéme možno identifikovat' tri rády hodnôt. Hodnotami prvého rádu sú základné hodnoty, na ktorých je založený celý systém. Bez ich prijatia nemôže nič nasledovat', lebo tvoria východisko celého systému. Hodnotami druhého rádu sú dôsledky základných hodnôt - druhotné, odvodené hodnoty. Hodnotami tretieho rádu sú špecifické stratégie a taktiky zamerané na uplatnenie hodnôt druhého rádu.

${ }^{4}$ Pokial' ide o otázku prevzatia zodpovednosti, odkazujem čitatel'a na monografiu autoriek D. Smrekovej a Z. Palovičovej (2009) Dvojznačnost' etických pojmov, na polemickú úvahu k nej z pera T. Sedovej (2010), na stat' D. Smrekovej (2010) Čo znamená prevziat' zodpovednost?? a na článok V. Mandu (2007) K niektorým filozofickým aspektom pojmu ,zodpovednost““.

${ }^{5}$ Pozri napríklad E. Smolková (2018).
} 
bol ohrozený istý obraz človeka - a to vel'mi špecifickými druhmi ohrozenia - pretože až zdesenie nad touto hrozbou nám môže dat' pravý obraz človeka“" (Jonas 1997, 56 - 57).

Podla Jonasovej heuristiky strachu (ako metodiky anticipujúcej zodpovednosti) by zlá prognóza, tá ktorá vzbudzuje obavy, mala mat' prednost' pred dobrou (tamže, 62). Obava z negatívnych vzdialených účinkov by nás mala motivovat', aby sme sa vyhli určitému konaniu, hoci by nám mohlo priniest' krátkodobý efekt.

Doteraz sme $v$ našej kultúre väčšinou uprednostňovali konanie prinášajúce krátkodobý prospech v ilúzii, že krátkodobé úspechy, ako postupnost' pozitívnych krokov (pokrok), povedú k dlhodobému prospechu. Navykli sme si stavat' najmä na pozitívnych očakávaniach v nádeji na ciel'ové dobro. Negatívne očakávania, ale aj konkrétne negatívne efekty, sme ignorovali, alebo sme ich pokladali za nutné vedlajšie a dočasné zlo na ceste $\mathrm{k}$ dobru.

Až súčasná environmentálna kríza a d’alšie dôsledky nášho doterajšieho meliorizmu nás nútia uvažovat' inak. Zaznávané vedlajšie dôsledky našej cesty $\mathrm{k}$ dobru sa premenili na reálnu hrozbu našej budúcnosti - a hlavne budúcnosti tých, čo prídu po nás.

Každá generácia modernej doby má ambíciu (alebo ju aspoň deklaruje) zanechat' potomkom o niečo lepší svet, ako je ten jej - svetlé zajtrajšky. Avšak vždy z toho pohl'adu, ako si toto zlepšenie predstavovala sama pre seba, nel’utujúc pritom úsilie ani prírodné zdroje - až natol'ko, že tým d'alším zostalo ovel'a menej zdrojov, než mali k dispozícii ich predchodcovia.

Jonas volá po novom pohl'ade do budúcnosti - píše, že meliorizmus neospravedlňuje to, aby sme dávali do stávky všetko (Jonas 1997, 69). Možno uvažovat' aj tak, že predsa nemôžeme vediet', či si naše vylepšenia sveta budú naši nasledovníci želat' (nehl'adiac na to, že už teraz naši najbližší proti nim protestujú!), ale dá sa odhadnút', čo im môže chýbat' a čo hrozit'. Aj preto by zlá prognóza mala mat' prednost' pred dobrou.

Jonas poukazuje na „osudovú zranitel'nost' prírody technickými zásahmi človeka zranitel'nost', ktorú netušil nikto predtým, než ju bolo možné poznat' v už spôsobených škodách“(Jonas 1997, 27). Charakter l’udského konania sa zmenil ,a k tomu, za čo musíme byt' zodpovední, lebo nad tým máme moc, pristúpil predmet celkom nového rádu, totiž celá biosféra planéty“ (tamže).

Je trochu paradoxné, že to, čo Jonas nazýva zranitel’nost’ou prírody, si viac ako dnešný človek uvedomovali l'udia prvotnopospolných spoločenstiev - a pocitovali aj strach, obavu pred vlastným rozvratným konaním. Prvotnopospolný človek chápal (a dnes ešte žijúce prírodné kultúry stále chápu) svet ako limitovaný, konečný, a uvedomoval si jeho zranitel'nost', narušitel'nost' i obmedzenost' jeho zdrojov. Vedomie, že môže zvrátit' poriadok sveta, v ňom vyvolávalo pocit vel'kej zodpovednosti. Obava pred narušením poriadku sveta a pred stratou či vyčerpaním životných zdrojov, ku ktorému by mohlo dôjst' $\mathrm{v}$ dôsledku nezodpovedného konania, bola spojená s úzkost'ou. Tá sa stala základom pre rozličné tabu. 
Bola to úzkost' z možných následkov vlastného zlyhania. Bremeno zodpovednosti za svet vyžadovalo nevybočit' zo zložitého cyklu prísnych rituálov. Kultová prax bola organickou súčast’ou svetového procesu. Zabezpečovala vít’azstvo rituálu ako univerzálneho organizujúceho princípu nad chaosom hroziacim celému svetu. Pohyb Mesiaca, Slnka i striedanie ročných období by sa nemohli uskutočnit', keby sa narušil cyklus rituálnych úkonov. Ale to bolo zároveň aj zdrojom nádeje. Dodržiavanie rituálov umožňovalo dúfat', že všetko bude tak, ako má byt'. Úzkost' vlastne podmieňovala nádej - viedla človeka $\mathrm{k}$ takému konaniu, ktoré dávalo nádej.

Príslušníci takýchto kultúr netúžili zanechávat' potomkom lepší svet, ale ani horší. Chceli im ho postúpit' taký, aký bol. Pokušenie menit' svet a zanechávat' ho potomkom lepší sa objavilo ovel'a neskôr a je spojené s ideou pokroku.

Podla L. Whitea (2000) naša súčasná viera v pokrok pramení v židovsko-krest’anskej tradícii. Zakladá sa na necyklickom, nevratnom a lineárnom chápaní postupnosti času, ale i na postupnosti stvorenia od menej dokonalého $\mathrm{k}$ dokonalejšiemu: zem - rastlinstvo živočísstvo - človek. Táto viera bola cudzia napríklad grécko-rímskej antike. Tu prevládala skôr predstava o cyklickom a vratnom svetovom procese.

Nazdávame sa, že to bola viera vyplývajúca z pochopenia nemožnosti návratu do východiskového stavu, viera v nevyhnutnost' postupu ku konečnému ciel'u (spáse), ktorá sa stala predpokladom ozajstnej idey pokroku, s ktorou prišla až renesancia ${ }^{6}$. Viera v nevyhnutnost' postupu vpred za určitým ciel'om s postupne sa zvyšujúcim presvedčením, že sa o to treba pričinit', bola psychologickým impulzom, ktorý podnecoval krest’anský svet $\mathrm{k}$ hl'adaniu ciest, metód, a nakoniec i technických riešení, ktoré potom predstavovali skutočný pokrok.

V krestanskom koncepte prvotného hriechu zrejme ešte rezonovali obavy prvobytného človeka, že je v jeho silách zvrátit' poriadok sveta. Človek sa nevyhol následkom zlyhania, dedí hriech a zodpovedá sa za to, ako vzdoruje tomu, čo spôsobil. Napriek všetkému krest’anstvo bolo a je prestúpené nádejou, vlastne sa z nej zrodilo. A z tejto nádeje sa zrodila aj viera v lepšie zajtrajšky - viera v pokrok.

Viera $\mathrm{v}$ pokrok viedla $\mathrm{k}$ uprednostňovaniu pozitívnych očakávaní a pozitívnych prognóz. Nesporné úspechy búrlivo sa rozvíjajúcej vedy a jej technických aplikácií v modernej dobe vyústili do scientistického optimizmu a technologického eudaimonizmu, do presvedčenia, že veda umožní človeku vyriešit všetky jeho problémy a skrotená príroda v podobe techniky mu bude slúžit' výlučne na jeho prospech. Skolimowski o tom pí̌e ako

\footnotetext{
${ }^{6}$ Renesancia nachádzala podobnost’ človeka s Bohom v tvorivých schopnostiach, najmä umeleckých, ale i technických. Človek mohol pokračovat' v stvorení, v d'alšom tvorení a rozvíjaní umelej druhej prírody. Tak mohol svet zdokonal'ovat'. Vo filozoficko-politickom kontexte je idea pokroku obsiahnutá v diele N. Machiavelliho Úvahy o prvej dekáde Tita Livia. Machiavelli na príklade vzájomných politických bojov rímskeho patriciátu a plebejstva poukazuje na pokrok, ktorý to prinieslo pri zdokonal'ovaní rímskeho práva a spoločnosti, a do istej miery poukazuje aj na jeho hybné sily (Machiavelli 1992).
} 
o faustovskom dedičstve - dedičstve vedecko-technických hodnôt, ktoré možno „zhrnút’ do jediného mocného mýtu: žijete iba raz, a preto žite riskantne, bez ohl'adu na to, čo to bude stát', aj keby to malo byt' na úkor ekologických habitatov alebo iných druhov či budúcich generácií“" (Skolimowski 1999, 190).

Rozvoj prírodovedy ani novoveké koncepcie panovania nad prírodou nás nepripravili na úlohu zodpovedných správcov prírody. A tak Jonas ponúka nový kategorický imperatív, ktorý by nám pomohol túto úlohu zvládnut': „Konaj tak, aby účinky tvojho konania boli zlučitel'né s trvaním skutočne l'udského života na Zemi! Konaj tak, aby účinky tvojho konania nezničili budúcu možnost' takého života! Neohrozuj podmienky neobmedzeného trvania l'udstva na Zemi!“ (Jonas 1997, 35)

Nový imperatív hovorí, že sa síce smieme odvážit' vystavit' nebezpečenstvu vlastný život, nie však život l'udstva. Že nemáme právo volit’ neexistenciu budúcich generácií na úkor existencií súčasných, alebo túto neexistenciu hoci len riskovat' (Jonas 1997, 35).

Nová etika zodpovednosti by mala byt' etikou naplnenou obavami o všetok pozemský život a metódou na zaistenie takejto zodpovednosti má byt' spomínané prebúdzanie strachu spojeného s anticipáciou možných hrozieb (heuristika strachu): „Máme na mysli strach, nie však odradzujúci od konania, ale do konania povzbudzujúci, ktorý bytostne patrí k zodpovednosti; a je to strach o predmet zodpovednosti“"(Jonas 1997,317). Tento predmet je zranitel'ný, a preto je čoho sa v súvislosti s ním obávat'. Zodpovednost' je za povinnost' uznaná starost' o iné bytie, ktorá sa pri ohrození jeho zranitel'nosti stáva obavou. „Ako možnost' však strach spočíva už v pôvodnej otázke, s ktorou si možno predstavit' počiatok každej aktívnej zodpovednosti: Čo sa mu stane, ked' sa ho ja neujmem? Č́́m nejasnejšia odpoved', tým jasnejšia zodpovednost'. A čím d’alej do budúcnosti, čím vzdialenejšie od vlastného blaha a bolestí a čím neznámejšie čo do svojho druhu je to, čoho sa strach týka, tým horlivejšie sa musia pre to mobilizovat' jasnozrivost', predstavivost' a citlivost' vnímavosti: nevyhnutná je skúmajúca heuristika strachu, ktorá pre seba nielen odhalí a zobrazí nový objekt, ale dokonca zoznámi týmto (a nikdy predtým) vyvolaný zvláštny mravný záujem so sebou samým“"(Jonas 1997, 317).

Koncept etiky zodpovednosti zameranej do budúcnosti rozvíja aj Skolimowski, pričom medzi špecifické a osobitne významné environmentálne hodnoty zarad'uje rozmanitost' (diverzitu) a s ňou spojenú environmentálnu (ekologickú) spravodlivost'.

Musíme konat' tak, aby sme zväčšovali a chránili rozmanitost' a zmenšovali či zastavili každú tendenciu k rovnorodosti, pretože rozmanitost' $=$ bohatstvo $=$ zložitost' $=$ život. Rozmanitost', bohatost', zložitost' foriem života je podmienkou jeho existencie a udržatel'nosti. Udržovat' a obohacovat' túto nenahraditel'nú podmienku rozkvetu života je naša morálna zodpovednost'. Morálka je osobitá vlastnost' skutočne l’udského života. Preto je morálnym imperatívom podporovat' tie sily, ktoré robia život životom a vedú $\mathrm{k}$ dozrievaniu jeho možností a k hojnosti ich foriem (Skolimowski 1996, 146). 
Environmentálna spravodlivost' pre všetkých je jednoduchým dôsledkom environmentálnej ohl'aduplnosti. Je dôsledkom myšlienky zodpovednosti za všetkých. „Ak kozmické tkanivo zahŕňa nás všetkých, ak je utkané z pramienkov, ktorých sme súčastou, potom spravodlivost' pre toto kozmické pradivo znamená spravodlivost' pre všetky jeho zložky, pre všetkých bratov a sestry stvoreného sveta, akoby povedali americkí Indiáni“ (Skolimowski 1996, 146).

Environmentálna spravodlivost' je dôsledkom úcty k životu, jeho rozmanitosti, ako i predpokladom jej udržania a obohatenia.

V súvislosti s uvádzanými hodnotami Skolimowski posudzuje stratégiu trvalo udržatel’ného rozvoja. Primárnou hodnotou pre túto koncepciu musí byt' hlboká úcta k životu. Vrcholným ciel’om celkového rozvoja musí byt' život. Rozvoj má slúžit životu. Ak život z tejto základnej rovnice vypustíme, zbavíme akýkol'vek pojem rozvoja zmyslu. Pritom nemá íst' o akýkol'vek život, ale o kvalitný život pre všetky živé bytosti. „Čo je jadrom pojmu rozvoj, nie je len biologický život, ale život naplnený zmyslom a dôstojnost'ou... poskytujúci sebarealizáciu“"(Skolimowski 1996, 147).

Ked' prijmeme princíp úcty k životu, umožní nám to skúmat' rozvoj nielen ako ekonomický jav, ale aj ako prostriedok na zlepšenie l’udského života na všetkých úrovniach. Úcta k životu nepopiera dôležitost' ekonomických faktorov - uspokojenie základných potrieb je súčastou dôstojného života.

Skolimowski operuje $\mathrm{v}$ tejto súvislosti radšej s pojmom úctyplného rozvoja. Úctyplnost' a ohl'aduplnost' $k$ životu sa musia stat' podstatnými vlastnost’ami rozvoja, ak sa rozvoj nemá stat' buldozérom drviacim krehkú prírodnú rovnováhu a zanechávajúcim vo svojej stope otupeného spotrebitel'a (Skolimowski 1996, 148).

Princíp úcty k životu sa zhoduje s mnohými náboženskými etikami, založenými na posvätnosti života, čo dokazuje, že jestvuje základné spoločné jadro etických hodnôt, spoločné všetkým národom a väčšine náboženstiev. Environmentálna (ekologická) etika tak predstavuje novú formuláciu tradičných hodnôt. Predstavuje hl'adanie zmyslu, dôstojnosti, zdravia a vyrovnanosti $\mathrm{v}$ čase, ked’ je Zem ohrozená neprimeraným a bezohl'adným rozvojom.

Úctyplný, ohladuplný rozvoj sa vyznačuje základnými hodnotami environmentálnej etiky, ako sú zodpovednost', striedmost' a ekologická spravodlivost' - u l'udí nemyslitel'ná bez sociálnej spravodlivosti. Preto ked' Skolimowski navrhuje ohl'aduplný rozvoj ako novú formu rozvoja, chce zároveň zaistit' trvalú udržatel'nost' našej planéty, priniest' dôstojnost' všetkým vykoristovaným a zjednotit' l'udstvo, ktoré je čoraz viac rozdel'ované neprimeraným rozvojom (Skolimowski 1996, 148).

Jonasov i Skolimowského koncept etiky zodpovednosti akoby bol návratom k etike prvobytných kultúr, u ktorých úzkost' a strach podmieňovali nádej, lebo úzkost' viedla človeka ku konaniu, ktoré dávalo nádej. Preto sa ani Jonas neobáva výčitky, že strach môže viest' $\mathrm{k}$ malomysel'nosti či negatívnemu postoju k budúcnosti, ked' ,vyhlasujeme strach za 
povinnost', ktorou môže byt' prirodzene len s nádejou (totiž na odvrátenie): odôvodnený strach, nie bojazlivost'; možno i úzkost', nie však ustráchanost'; a v žiadnom prípade nie strach alebo úzkost' kvôli nám samotným. Ustupovat' úzkosti z cesty tam, kde je namieste, by bolo v skutočnosti ustrašenost'ou“ (Jonas 1997, 317 -318).

Nový imperatív a heuristika strachu kladú väčšie nároky aj na zodpovednost' odborníkov za dostatočnú informovanost' osôb či skupín prijímajúcich rozhodnutia, ktoré sa týkajú budúcnosti. Vzhl’adom na svoju kompetenciu sú povinní poukázat' aj na hrozby a nebezpečné riziká spojené s týmito rozhodnutiami. Ich odborné svedomie by nemalo byt' zamerané len na krátkodobé efekty, ale malo by sa motivovat' aj obavami o možné následky a podobu dedičstva, ktoré zanecháme budúcim generáciám. Vzhl'adom na budúcnost' nemôže platit doterajšia alibistická predstava, že vedec či tvoriaci inžinier nie sú zodpovední za to, na čo sa ich objavy a výtvory použijú (komu a na čo ich zveria) a čo $\mathrm{v}$ dôsledku toho spôsobia.

Jonas za objekt svojej anticipujúcej zodpovednosti pokladá budúce generácie l’udstva a prírodné podmienky ich života. Kladie človeku za úlohu byt' správcom prírody. Vychádza pritom z predpokladu, že príroda je človeku zvereným dobrom (Jonas 1997, 29).

Ale jeho myšlienku, že sme zodpovední za to, nad čím máme moc (tamže, 27), si možno vyložit' aj tak, že prevzatiu správcovstva, nemusí predchádzat' akt zverenia. Môže to byt' aj akt uzurpácie. A nám to skôr pripadá tak, že človek si postavenie správcu prírody uzurpoval.

Vyjadrili sa k tomu už priekopníci novovekej filozofie, pričom tento akt spojili s poznávaním - vedou: „Luudské poznanie a l’udská moc sú jedno a to isté“ (Bacon 1966, 257). Poznanie prírody je cestou k jej opanovaniu, a preto zmyslom vedy je „poznávat' príčiny a skryté pohyby vecí a rozširovat' hranice l'udského panstva na všetky myslitel'né veci“ (Bacon 1980, 281). Descartes volá po novej praktickej filozofii,““... pomocou ktorej, poznajúc silu a pôsobnost' ohňa, vody, hviezd, oblohy a všetkých ostatných telies nás obklopujúcich..., mohli by sme všetko toto použit'... na všetky účely, na ktoré sa to hodí, a stat' sa tak akoby pánmi a vlastníkmi prírody" (Descartes 1992, 45). J. Locke naznačuje možnost' zdôvodnenia aktu uzurpácie prácou človeka: „Práca jeho tela a dielo jeho rúk... sú vo vlastnom zmysle jeho. Čokol'vek teda vyjme zo stavu, ktorý príroda tomu prepožičala a v ktorom to ponechala, zmieša s tým svoju prácu a pripojí k tomu niečo, čo je jeho vlastné, robí tak svojím vlastníctvom“ (Locke 1992, 45). Ešte si netrúfa ponechat’ právo človeka disponovat' prírodou na jeho l'ubovôlu a odvodzuje ho od Boha, ktorý dal človeku rozum: „Zem a všetko, čo je na nej, je dané l'ud’om spoločne na udržiavanie a pohodu ich existencie..." a „Boh a rozum... nariad'ovali podmanit' si Zem, teda zvelebovat' ju na prospech života..." (tamže, 47). Myslitelia svetskejšieho razenia, napríklad utilitaristi, tento dôvod už nepotrebovali a ludskú prácu spätú s poznaním prijímali ako zdroj nášho správcovstva prírody (či presnejšie - panovania nad ňou). 
Avšak aj akt uzurpácie núti k zodpovednosti za uzurpované. Bremeno zodpovednosti za prírodu sme si tak naložili sami. $V$ dôsledku rozvoja prírodných vied a ich materializácie $\mathrm{v}$ technike vzrástla miera našich zásahov do prírody na takú úroveň, že to môže viest' $\mathrm{k}$ zničeniu života na našej planéte. A zodpovednosti za to sa už zbavit' nemôžeme!

\section{Literatúra}

BACON, F. (1966): Nové organon. In: Antológia z diel filozofov. Humanizmus a renesancia. Bratislava: Vydavatel'stvo politickej literatúry, 253 - 306.

BACON, F. (1980): Nová Atlantida a eseje. Praha: Mladá fronta.

DESCARTES, R. (1992): Rozprava o metodè. Praha: Svoboda.

JONAS, H. (1997): Princip odpovédnosti. Pokus o etiku pro technologickou civilizaci. Praha: Oikúmené.

LEOPOLD, A. (1996): Etika země. In: Kohák, E. - Kolářský, R. - Míchal, I. (eds.): Závod s časem. Texty z morálni ekologie. Praha: Torst, 35 - 49.

LOCKE, J. (1992): Druhé pojednáni o vládě. Praha: Svoboda.

MACHIAVELLI, N. (1992): Vladár - Úvahy o prvej dekáde Tita Livia - Vojenské umenie. Bratislava: Tatran.

MANDA, V. (2007): K niektorým filozofickým aspektom pojmu „zodpovednost““. In: Špirko, D. (ed.): Zodpovednost' odborníka (inžiniera, manažéra, učitel'a) v súčasnom svete. Bratislava: STU, $93-98$.

NAESS, A. (1993): Ekologie, pospolitost’ a životni styl. Tulčík: Abies.

SEDOVÁ, T. (2010): Malá úvaha nad jedným pokusom o rozlíšenie medzi etikou a morálkou: Smreková, D., Palovičová, Z.: Dvojznačnost' etických pojmov. Filozofia, 65 (5), 493 - 498.

SCHWEITZER, A. (1996): Etika úcty k životu. In: Kohák, E. - Kolářský, R. - Míchal, I. (eds.): Závod s časem. Texty z morální ekologie. Praha: Torst, $21-34$.

SKOLIMOWSKI, H. (1996): Ekologická etika a posvátnost života. In: Kohák, E. - Kolářský, R. Míchal, I. (eds.): Závod s časem. Texty z morálni ekologie. Praha: Torst, 135 - 152.

SKOLIMOWSKI, H. (1999): Živá filozofia. Ekofilozofia ako strom života. Prešov: Slovcontact.

SKOLIMOWSKI, H. (2001): Účastná mysl. Nová teorie poznání a vesmíru. Praha: Mladá fronta.

SMOLKOVÁ, E. (2018): K otázke vplyvu Hansa Jonasa na súčasnú etiku. Filozofia, 73 (9), 731 741.

SMREKOVÁ, D. (2010): Čo znamená prevziat’ zodpovednost? K pojmu imputácie v súčasnej etike. Filozofia, 65 (9), $893-906$.

SMREKOVÁ, D., PALOVIČOVÁ, Z. (2009): Dvojznačnost' etických pojmov. Bratislava: Filozofický ústav SAV.

SŤAHEL, R. (2015): Environmentálna zodpovednost' a environmentálna bezpečnost'. Filozofia, 70 (1), $1-12$.

SŤAHEL, R. (2018): Environmentalizmus ako politická filozofia pre 21. storočie. Filozofia, 73 (1), $1-13$.

ŠPIRKO, D. (1996): Človek v ústredí alebo v ústraní? Filozofia, 51 (2), 106 - 111.

ŠPIRKO, D. (2011): Biocentrizmus, humanizmus, zodpovednost'. In: Krchnák, P. (ed.): (Úvahy) O biocentrizme a humanizme. Zvolen: TU, 12 - 19. 
WHITE, L. Jr. (2000): Historické kořeny naší ekologické krize. Filosofický časopis, 48 (5), $765-775$.

Príspevok vychádza v rámci riešenia projektu VEGA č. 1/0291/18 Historicko-filozofická analýza environmentálneho myslenia, skúmanie jeho vplyvov na etické, právne a politické myslenie a jeho spoločenská odozva.

Dušan Špirko

Katedra filozofie

Filozofická fakulta UKF v Nitre

Hodžova 1

94974 Nitra

Slovenská republika

e-mail: dspirko@ukf.sk 